\title{
四面体要素の発生・消滅を伴う移動格子有限体積法
}

\section{Moving-Grid Finite-Volume Method with Addition and Elimination of Tetrahedrons}

\author{
○学 光成 直也・京工繊大院 \\ Naoya MITSUNARI \\ Kyoto Institute of Technology \\ Matsugasaki Kyoto
}

\author{
正 山川 勝史・京工繊大 \\ Masashi YAMAKAWA \\ Kyoto Institute of Technology \\ Matsugasaki Kyoto
}

\author{
正 松野謙一・京工繊大 \\ Kenichi MATSUNO \\ Kyoto Institute of Technology \\ Matsugasaki Kyoto
}

Key Words: Moving-Grid Finite-Volume Method, Unstructured Mesh, Compressible Flow

\section{1. 諸言}

ロケット打ち上げ過程にある補助ロケットの分離などの ような複雑な移動・変形を伴う物体周りの流れ場は広くみら れる.これらは移動境界問題と呼ばれ，その一つの計算手法 として，時間と空間を合わせた検查体積を考慮し定式化した 移動格子有限体積法(1)がある.ただし，複雑な変形を伴う場 合には, 格子の移動に伴い計算要素の疎密や歪な形状の要素 の発生を引き起こしてしまう可能性があり，それが計算精度 の低下に槃がってしまう恐れがある。

そこで著者らは上記の問題を解決するため, 格子の疎密に 合わせて随時格子点を追加・削除する方法(2)を提案している. 計算要素が桩大する場合には新たな格子点を追加し, 縮小す る場合には格子点を削除し，要素を常に均一化することで， 高い精度を維持したままの計算が期待できる. しかし非構造 格子系においては，そのアルゴリズムが非常に複雑となるこ となどを理由に, この手法は実用上重要な意味を持つ 3 次元 化には到達していなかった。

以上より, 本研究ではこの手法を 3 次元の非構造格子系に 拡張して, 計算スキームに対する検証を行い, その有効性を 確認した。 また，移動境界問題としてピストンの圧縮問題を 取り扱い，本手法の実用性を示した。

\section{2. 基礎方程式}

基礎方程式として, 非粘性圧縮性流体に対する次式で示さ れる無次元化された 3 次元オイラー方程式を用いる.

$$
\frac{\partial \mathbf{q}}{\partial t}+\frac{\partial \mathbf{E}}{\partial x}+\frac{\partial \mathbf{F}}{\partial y}+\frac{\partial \mathbf{G}}{\partial z}=0
$$

ここで， $\mathbf{q}$ は保存量ベクトル， $\mathbf{E}, \mathbf{F}, \mathbf{G}$ はそれぞれ $x, y, z$ 方向 の非粘性流束べクトルである.

\section{3 次元非構造移動格子有限体積法 \\ 3-1 移動格子有限体積法 ${ }^{(3)}$}

時間の経過とともに格子が移動すると，時間と空間を合わ せた領域における検査体積を考える必要がある. 3 次元空間 の場合, 検查体積は Fig. 1 に示すような $n$ 時間段階と $n+1$ 時 間段階のセルによって形成される 4 次元的な体積となる.

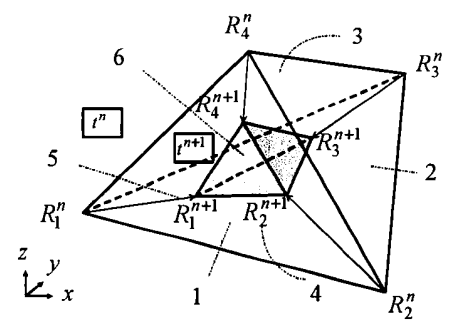

Fig.1 Control volume
式(1)について Fig.1 に示す検査体積のもとで体積積分を行 い,さらにガウスの発散定理を用いることによって, 次式が 得られる.

$$
\begin{aligned}
& \sum_{l=1}^{6}(\tilde{\mathbf{F}} \cdot \tilde{\mathbf{n}})_{l}=0 \\
& \widetilde{\mathbf{F}}=[\mathbf{E}, \mathbf{F}, \mathbf{G}, \mathbf{q}]^{T}, \quad \widetilde{\mathbf{n}}=\left[n_{x}, n_{y}, n_{z}, n_{t}\right]^{T}
\end{aligned}
$$

ここで, $l=1,2, \ldots, 6$ は検査体積内の各体積を表し， $\tilde{\mathbf{n}}$ はそれ ぞれの外向き法線ベクトルを示す. ただし， $l=5$ および 6 は それぞれ, $n$ および $n+1$ 時間段階での四面体セルの体積であ り, 法線ベクトルは $t$ 方向成分しか持たないため, 式(2)は次 式のように変形できる.

$$
\mathbf{q}^{n+1}\left(n_{t}\right)_{6}+\mathbf{q}^{n}\left(n_{t}\right)_{5}+\sum_{l=1}^{4}(\tilde{\mathbf{F}} \cdot \tilde{\mathbf{n}})_{l}^{n+1 / 2}=0
$$

式(4)を解くことによって, 格子の移動が流れ場に影響を与え ない, すなわち幾何保存則を満足したまま計算を行うことが できる.

\section{3-2 計算要素の発生を伴う移動格子有限体積法}

新たな四面体要素を発生させる際, 四面体の 1 辺上に格子 点を追加し, 要素の分割を行う。この時, Fig.2 に示すよう な検査体積のもとで幾何保存則を満たす離散化を行う必要 がある. 要素 A については式(4)の離散式を用い，新たに発 生する要素 B については $n$ 時間段階での体積が 0 となるの で, 式(4)において, $\left(n_{t}\right)_{5}=0$ となり, 離散式は次式となる.

$$
\mathbf{q}^{n+1}\left(n_{t}\right)_{6}+\sum_{l=1}^{4}(\tilde{\mathbf{F}} \cdot \tilde{\mathbf{n}})_{l}^{n+1 / 2}=0
$$

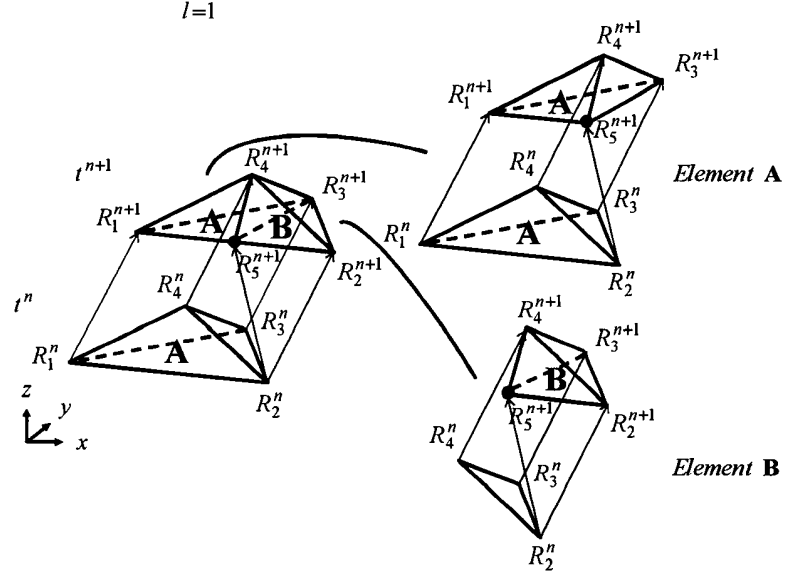

Fig.2 Control volume in the case of division 


\section{3-3 計算要素の消滅を伴う移動格子有限体積法}

既存の四面体要素を消滅させる際, 四面体の 1 辺を構成す る 2 つの格子点を重祮合わせる.この時, Fig.3に示すよう な $n$ 時間段階における要素 $\mathbf{A}$ と要素 $\mathbf{B}$ を合わせた検查体積 のもとで離散化を行う。よって, 解くべき離散式は式(3)につ いて $n$ 時間段階の 2 つの要素を合わせた次式となる.

$$
\mathbf{q}_{\mathbf{A}}^{n}\left\{\left(n_{t}\right)_{7}\right\}_{\mathbf{A}}+\mathbf{q}_{\mathbf{B}}^{n}\left\{\left(n_{t}\right)_{7}\right\}_{\mathbf{B}}+\mathbf{q}_{\mathbf{A}}^{n+1}\left\{\left(n_{t}\right)_{8}\right\}_{\mathbf{A}}+\sum_{l=1}^{6}(\tilde{\mathbf{F}} \cdot \widetilde{\mathbf{n}})_{l}^{n+1 / 2}=0(6)
$$

Fig. 3 Control volume in the case of union

ここで非粘性流束ベクトル $\tilde{\mathbf{F}}$ はRoe の流束差分離法 ${ }^{(4)}$ を用 いて評価する.また, 空間高次精度化には数值振動を抑制す るため, Venkatakrishnan の制限関数 ${ }^{(5)}$ 用いる. 式(4)〜 (6) を解くための擬似時間内部反復法には 2 段階有理 Runge-kutta 法を用いる.

\section{4. 幾何保存則に対する検証}

Fig.4 に示す $1.0 \times 1.0 \times 1.0$ の計算領域内に一様流を流した. この時, 内部の格子点を移動および追加・削除させても，流 れ場に影響を与えることなく計算できるか確認した。

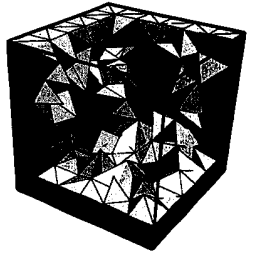

(a) $t=0.0$

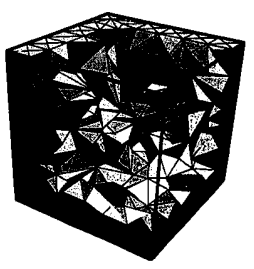

(c) $t=5.0$

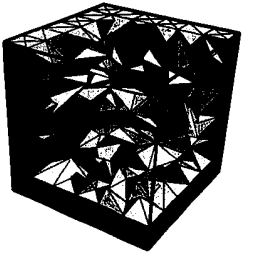

(b) $t=2.5$

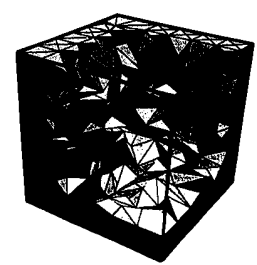

(d) $t=7.5$
Fig.4 Moving grids with addition and elimination of elements

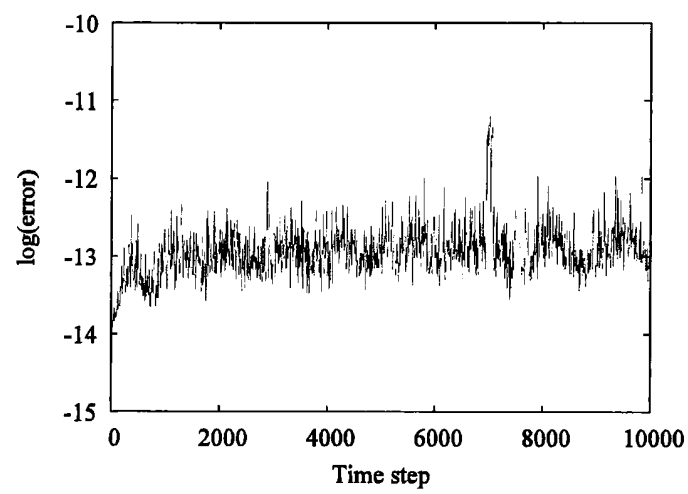

Fig.5 Error of density
Fig.5 に示すように密度の初期值との誤差が $10^{-14}$ から $10^{-12}$ のオーダーであったことから，本手法が幾何保存則を 満足しながら計算できることが確認できた.

\section{5. 移動境界問題に対する検証}

Fig.6に示すように, 次式に示すピストン速度 $U_{p}$ で $1.5 \times 0.5 \times 0.5$ のシリンダー内の空気を圧縮させる.

$$
U_{p}= \begin{cases}10 t & t<0.1 \\ 1.0 & t \geq 0.1\end{cases}
$$

その際に生じる衝撃波の位置における厳密解 ${ }^{(6)}$ との比較を Fig.7に示しており，これらが良好に一致していることから， 本手法が移動境界問題にも適用可能なことが確認できた。

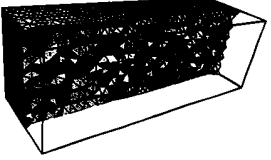

(a) $t=0.0$

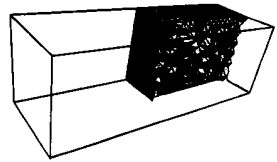

(c) $t=0.8$

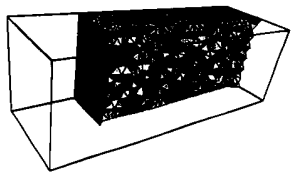

(b) $t=0.4$

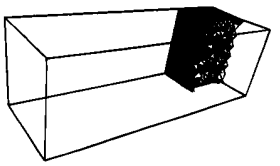

(d) $t=1.2$
Fig.6 Computational grids for piston compression

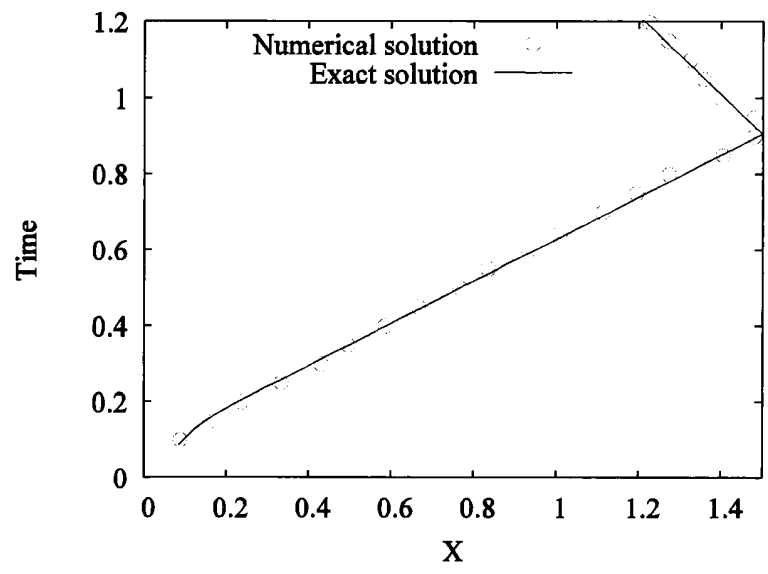

Fig.7 Shock wave positions

\section{6. 結言}

非粘性圧縮性流れに対して, 要素の発生・消滅を伴う非構 造移動格子有限体積法を 3 次元へ拡張させ, 計算を行ったこ とにより以下の結論を得た.

- 本手法は幾何保存則を完全に満たし，その有効性を 示した。

- 移動境界問題に適用できたことから，本手法の高い 応用性を示した。

\section{参考文献}

(1)三原 他 2 名, 機論, 65-637, B(1999), 2945-2953

(2)山川，松野，機論, 70-689, B(2004), 25-30

(3)山川, 松野, 機論, 69-683, B(2003), 1577-1582

(4)Roe,P.L.,Journal of Computational Physics, 43,(1981), 357-372

(5)Venkatakrishnan V., AIAA Paper , 93-0880, (1993)

(6)生井, 松尾, 衝撃波の力学, (1983), コロナ社 